\title{
Histone H2B Type F-S
}

National Cancer Institute

\section{Source}

National Cancer Institute. Histone H2B Type F-S. NCI Thesaurus. Code C162840.

Histone H2B type F-S (126 aa, 14 kDa) is encoded by the human H2BS1 gene. This protein is involved in histone-mediated processes and innate immunity. 